\title{
Penyembuhan Luka Pasca Kastrasi pada Kucing Jantan dengan Menggunakan Sediaan Propolis Cair
}

\section{Healing of Post-Castration Wounds in Male Cats Using Liquid Propolis Preparations}

Fera Aryanti ${ }^{1 *}$, Farissa Romadhiyati ${ }^{2}$

${ }^{1}$ Widyaiswara Balai Besar Pelatihan Kesehatan Hewan Cinagara - Bogor, Indonesia

${ }^{2}$ Balai Besar Pelatihan Kesehatan Hewan Cinagara - Bogor, Indonesia

*feraaryanti@pertanian.go.id

Sejarah Artikel:

Dikirimkan:

28 Februari 2021

Diterima:

7 Juli 2021

Terbit:

26 Juli 2021
Propolis sejak jaman dahulu sudah digunakan untuk menyembuhkan luka karena mengandung arginin dan asam ferulat dimana kedua senyawa ini memacu pembentukan kolagen. Penelitian ini bertujuan untuk mengidentifikasi tingkat keefektifan penyembuhan luka sayatan kastrasi pada kucing dengan menggunakan sediaan propolis cair yang banyak beredar di pasaran. Sebanyak 16 ekor kucing jantan dikastrasi dengan metode terbuka. Setelah itu kucing dibagi menjadi 2 kelompok. Kelompok 1 sebanyak 12 ekor diberi pengobatan propolis cair 1 tetes sebanyak 2 kali pemberian yaitu sesaat setelah kastrasi dan hari ke-2 (H.2) setelah kastrasi. Kelompok 2 sebanyak 4 ekor kucing hanya diberi 1 kali propolis cair dengan jumlah yang sama sesaat setelah kastrasi. Proses persembuhan luka sayat kastrasi diamati selama 5 hari. Data yang telah didapat kemudian dianalisis secara deskriptif dengan membandingkan gambaran proses persembuhan luka sayatan operasi serta waktu proses kesembuhan. Dari kedua kelompok perlakuan ini menunjukkan bahwa secara keseluruhan sampel menunjukkan penyembuhan luka sempurna pada hari ketiga (H.3) pasca kastrasi. Pemberian propolis cair yang dilakukan 1 kali sesaat setelah kastrasi ternyata mampu menunjukkan waktu persembuhan luka sayatan kastrasi yang sama dengan pemberian propolis cair yang dilakukan sebanyak 2 kali

Since ancient times, propolis has been used to heal wounds because it contains arginine and ferulic acid, both of which stimulate collagen formation. This study aims to identify the effectiveness of castration wound healing in cats using liquid propolis preparations which are widely available in the market. 16 male cats were castrated using the open method. After that the cats were divided into 2 groups. Group 1, 12 individuals, were given 1 drop of liquid propolis treatment 2 times, shortly after castration and day 2 (H.2) after castration. Group 2 consist of 4 cats was only given 1 time with the same amount of liquid propolis immediately after castration. The healing process of castration incisions was observed for 5 days. The data were analyzed descriptively by comparing the description of the process of healing the surgical incision wound and the time of the healing process. From the two treatment groups, it shows that the overall sample shows complete wound healing on the third day (H.3) after castration. The administration of liquid propolis which was done once immediately after castration was able to show the healing time of the castration incision wound which was the same as the administration of liquid propolis which was carried out twice.

This is an open access article under the CC-BY license.

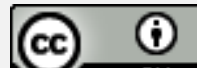

Kata Kunci: BBPKH Cinagara, Kucing, Kastrasi, Orchiectomy, Propolis

Keywords: BBPKH Cinagara, Cat, Castration, Orchiectomy, Propolic

\section{Pendahuluan}

Menurut UU No.18 Tahun 2009 tentang Peternakan dan Kesehatan Hewan, Hewan Peliharaan adalah hewan yang sebagian atau seluruhnya kehidupannya bergantung pada manusia untuk maksud tertentu sedangkan Hewan Kesayangan adalah hewan yang dipelihara khusus sebagai hewan olah raga, kesenangan, dan keindahan. Hewan Kesayangan seperti anjing dan kucing dapat membawa dan menularkan berbagai agen penyakit secara langsung karena kontak yang begitu dekat dengan manusia dan begitu pula sebaliknya (zoonosis), misalnya saja 
Penyakit Rabies yang sampai saat ini masih sulit untuk diberantas dan juga penyakit toksoplasmosis yang dapat ditularkan melalui kucing liar yang dapat menyebabkan keguguran bagi ibu hamil (Dachlan, 2004). Peningkatan populasi anjing dan kucing, khususnya yang berkeliaran di jalanan, menjadi masalah tersendiri bagi kesehatan manusia. Populasi hewan kecil yang tidak terkontrol adalah suatu masalah yang harus dipecahkan (Mughniati, et al, 2018). Peningkatan populasi kucing dapat diatasi dengan cara melakukan pengendalian populasi salah satunya melalui kastrasi atau ovariohisterektomi. Kastrasi merupakan solusi yang cukup efektif untuk mengurangi lonjakan populasi kucing liar (Abdurrahman et al. 2017).

Sterilisasi adalah operasi pengangkatan organ reproduksi pada hewan agar tidak dapat berkembang biak. Pada hewan jantan disebut dengan kastrasi / orchiectomy, sedangkan pada hewan betina disebut ovariohysterectomy $(\mathrm{OH})$. Kastrasi atau orchiectomy adalah suatu tindakan pembedahan dibawah anestesi umum untuk mengangkat (menghilangkan) testiskel dan korda spermatika dengan tujuan menghasilkan sterilitas. Manfaat lain kastrasi pada kucing dan anjing jantan diantaranya adalah mengurangi spraying dan marking; mengurangi dan mencegah kejadian penyakit hormonal dan tumor testis, hernia, Gangguan Kelenjar Prostat serta mengurangi agresif di masa kawin dan keinginan berkeliaran di luar rumah.
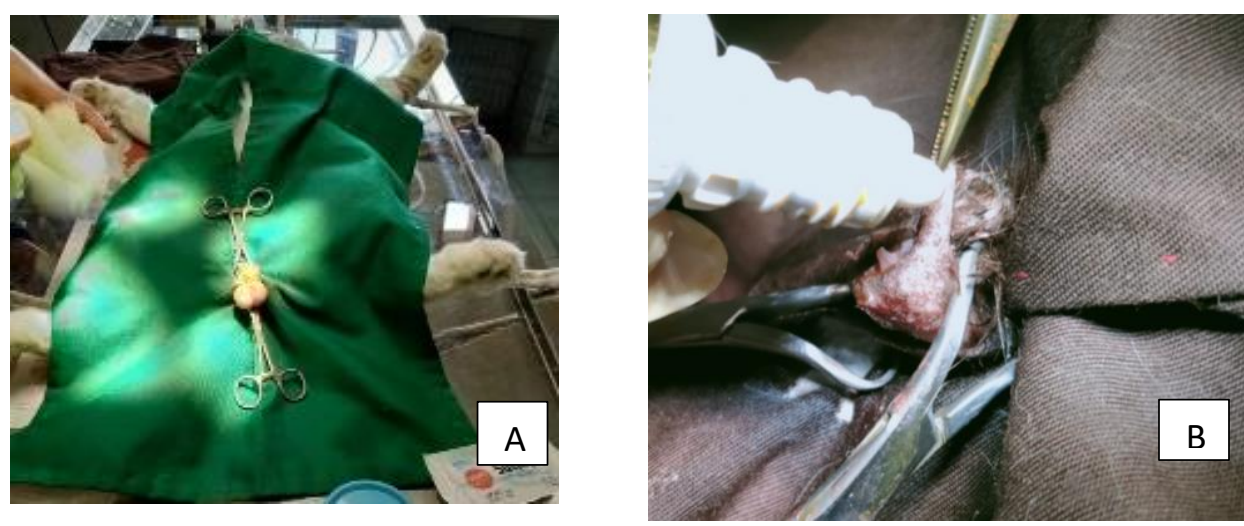

Gambar 1. Teknik kastrasi pada kucing jantan

Keterangan:

A. Persiapan Kastrasi, sebelum dilakukan penyayatan pada kulit skrotum dan pemotongan organ testis pada kucing jantan.

B. Pemberian tetesan propolis cair ke dalam luka operasi dan luka sayatan kulit skrotum.

Keberhasilan kastrasi ditentukan oleh pengobatan dan perawatan pasca operasi. Luka pasca operasi harus diobati supaya lekas kering dan hewan dapat kembali sehat seperti semula. Manajemen perawatan luka yang tepat diperlukan untuk mempercepat proses penyembuhan, mencegah kerusakan kulit dan jaringan sekitarnya, mengurangi risiko infeksi, dan juga untuk meningkatkan kenyamanan pasien.

Salah satu produk dari lebah yang digunakan masyarakat sejak jaman dahulu untuk menyembuhkan luka adalah propolis. Propolis mengandung arginin (jenis asam amino) dan asam ferulat (turunan senyawa sinamat) dimana kedua senyawa ini memacu pembentukan kolagen. Propolis juga kaya dengan kandungan polyphenolic terdapat flavonoid dan senyawa lain yang memiliki sifat antibakteri, antivirus, antijamur dan memiliki efek imunomodulasi (Susilo, et al. 2009) . Propolis umumnya dikenal sebagai "lem lebah", yang merupakan nama generik yang mengacu pada zat resin yang dikumpulkan oleh lebah dari berbagai jenis tanaman. Kata propolis berasal dari bahasa Yunani yang berarti pertahanan untuk "pro" dan kota atau komunitas untuk "polis", yang dapat diartikan sebagai atau sarang lebah. Propolis berfungsi untuk menutup lubang dan retakan serta untuk merekonstruksi sarang lebah. Hal ini juga digunakan untuk menghaluskan permukaan bagian dalam sarang lebah, mempertahankan suhu internal sarang $\left(35^{\circ} \mathrm{C}\right)$, mencegah pelapukan dan invasi oleh predator. Selanjutnya, propolis mengeraskan dinding sel dan berkontribusi pada lingkungan internal yang aseptik (Pasupuleti et al, 2017).

Keragaman jenis perawatan luka pada hewan selama ini tidak didukung oleh dokumentasi yang menjelaskan tingkat keberhasilan masing-masing perawatan dalam proses penyembuhan pasien. Peneliti tertarik untuk mengidentifikasi tingkat keefektifan penyembuhan luka sayatan kastrasi pada kucing dengan menggunakan sediaan propolis cair yang banyak beredar di pasaran sehingga nantinya dapat menjadi salah satu alternatif pengobatan perawatan luka pasca operasi. 


\section{Metodologi}

\subsection{Lokasi dan Waktu Penelitian}

Tempat penelitian dan penanganan operasi kastrasi dilakukan di Klinik Hewan Sehat Balai Besar Pelatihan Kesehatan Hewan (BBPKH) Cinagara - Bogor mulai dari Bulan Maret 2019 hingga Bulan Juni 2020.

\subsection{Alat dan Bahan Penelitian}

Alat yang digunakan dalam penelitian ini terdiri dari Alat Bedah Minor yang terdiri dari Pinset Cirurgis, Pinset Anatomis, Gunting Jaringan Tajam, Gunting Jaringan Tumpul, Needle Holder, Mosquito Lurus, Mosquito Bengkok, Kocher Lurus, Kocher Bengkok, Scalpel Handle, Scalpel Blade, Suture Chromic Cat Gut dengan merek (R) One Med.

Bahan yang digunakan dalam penelitian ini antara lain Atropin sulfat, Xylazin, dan Ketamin Hidrochlorida sebagai obat anasthesi umum. Iodium Tictur 3\%, Kasa steril, Kapas, Alkohol 70\%, Serta Sediaan jadi Propolis Cair dengan merek ${ }^{\circledR}$ Melia Propolis yang mengandung $900 \mathrm{mg}$ Propolis Liquid sebagai bahan dan obat perawatan pasca kastrasi.

\subsection{Subjek Penelitian}

Subjek dalam penelitan ini adalah kucing jantan pasca tindakan operasi kastrasi sebanyak 16 ekor. Kriteria untuk menentukan sampel adalah kucing jantan dengan variasi umur antara 7 bulan sampai 30 bulan.

\subsection{Prosedur Kerja}

Penelitian dilakukan pada 16 Kucing Jantan menggunakan teknik kastrasi dengan metode terbuka. Teknik Kastrasi dilakukan dengan memberikan premedikasi Atropin Sulfat dengan dosis 0,02 mg/kg BB. Atropin digunakan sebagai premedikasi yang bertujuan untuk mengatasi efek depresi yang ditimbulkan dari sediaan anaesthesi (Rahmiati \& Wira, 2019). Setelah 10 hingga 15 menit kemudian dilakukan general anestesi dengan pemberian Xylazin dosis $10 \mathrm{mg} / \mathrm{kg}$ BB dan Ketamin Hidrochlorida dengan dosis 6 mg/kg BB (Arnbjerg, 1979), Pemberian secara intramuscular. Kombinasi keduanya dinilai efektif sebagai sediaan yang mampu menghilangkan kesadaran dan menimbulkan efek muscle relaxant yang baik. Akan tetapi, sefek samping dari kombinasi keduanya pada kucing adalah hipotermia, penurunan frekuensi denyut jantung, frekuensi pernafasan, cardiac output, serta tekanan darah (Allen et al, 1986).

Skrotum dibuka pada bagian median dan diinsisi testis di bagian sinister dan dexter yang selanjutnya dikeluarkan dan diligasi pada bagian spermatic cord, lalu kemudian dipotong (Sardjana \& Kusumawati, 2011). Panjang sayatan pada kulit skrotum dexter dan sinister masing-masing sepanjang $1 \mathrm{~cm}$. Kastrasi yang dilakukan pada penelitian ini adalah kastrasi dengan membuang testiskel dan korda spermatika dengan menggunakan metode kastrasi terbuka. Akhir dari tindakan kastrasi tidak dilakukan penjahitan pada kulit skrotum. Luka operasi dibiarkan terbuka dengan tujuan agar luka sayatan baik di dalam maupun di kulit skrotum cepat mengering. Sediaan Propolis cair diteteskan ke dalam luka operasi sebanyak 1 tetes dan juga di sepanjang sayatan kulit skrotum dexter dan sinister masing-masing sebanyak 1 tetes. Pada kelompok pertama sebanyak 12 ekor kucing jantan, pemberian sediaan propolis cair diulang kembali H.2 atau keesokan harinya sebanyak 1 tetes di sepanjang sayatan kulit skrotum dexter dan sinister dengan frekuensi pemberian satu kali sehari. Kelompok kedua sebanyak 4 ekor, pemberian tetes propolis cair tidak dilakukan pengulangan. Propolis cair hanya diberikan di akhir setelah proses kastrasi selesai. Luka pasca operasi untuk kelompok 1 dan 2 diamati selama 5 hari.

Pengambilan data dilakukan dengan mendokumentasikan dengan foto dan mencatat proses penyembuhan luka sayatan kulit skrotum pasca kastrasi setiap harinya. Data dianalisis secara deskriptif dengan membandingkan gambaran proses persembuhan luka sayatan operasi serta waktu proses kesembuhan.

\section{Hasil dan Pembahasan}

\subsection{Hasil}

Selama lima hari pasca kastrasi, dilakukan pengamatan pada luka sayatan. Parameter yang diamati dalam penelitian ini adalah ada tidaknya eritrema (bintik hingga bercak kemerahan pada kulit yang disebabkan pelebaran pembuluh darah, pembengkakan disekitar luka sayatan, dan menutupnya jaringan bekas sayatan). 
Hasil penelitian berupa tahapan persembuhan luka sayatan kucing jantan pasca operasi kastrasi ditunjukan pada Tabel 1.

Tabel 1. Penyembuhan luka pasca kastrasi

\begin{tabular}{|c|c|c|c|c|c|c|}
\hline \multirow[t]{2}{*}{ HEWAN } & \multicolumn{6}{|c|}{ WAKTU SAAT \& PASCA KASTRASI (Hari) } \\
\hline & H.O & $H .1$ & H.2 & H.3 & H.4 & $H .5$ \\
\hline K.1 & $\bullet * *$ & $\bullet *$ & + & $\sqrt{ }$ & & \\
\hline K.2 & $\bullet * *$ & $\bullet * *$ & $\bullet *$ & + & $\sqrt{ }$ & \\
\hline K.3 & $\bullet * *$ & $\bullet *$ & + & $\sqrt{ }$ & & \\
\hline K.4 & $\bullet * *$ & $\bullet * *$ & $\bullet *$ & + & $\sqrt{ }$ & \\
\hline K. 5 & $\bullet * *$ & $\bullet *$ & + & $\sqrt{ }$ & & \\
\hline K.6 & $\bullet * *$ & $\bullet *$ & + & $\sqrt{ }$ & & \\
\hline K.7 & $\bullet * *$ & $\bullet *$ & + & $\sqrt{ }$ & & \\
\hline K. 8 & $\bullet * *$ & $\bullet *$ & + & $\sqrt{ }$ & & \\
\hline K.9 & $\bullet * *$ & $\bullet *$ & + & $\sqrt{ }$ & & \\
\hline K.10 & $\bullet * *$ & $\bullet *$ & + & $\sqrt{ }$ & & \\
\hline K.11 & $\bullet * *$ & $\bullet *$ & + & $\sqrt{ }$ & & \\
\hline K.12 & $\bullet * * *$ & $\bullet *$ & + & $\sqrt{ }$ & & \\
\hline K.13 & $\bullet * *$ & + & $\sqrt{ }$ & & & \\
\hline K.14 & $\bullet * *$ & + & $\sqrt{ }$ & & & \\
\hline K.15 & $\bullet * *$ & $\bullet *$ & + & $\sqrt{ }$ & & \\
\hline K.16 & $\bullet * *$ & $\bullet *$ & + & $\sqrt{ }$ & & \\
\hline
\end{tabular}

Keterangan Tabel:

K.1-K.16 Kucing Jantan yang menjadi pasien operasi kastrasi

H.0 Hari dilakukan operasi kastrasi

H.1-H.5 Hari pasca operasi kastrasi

. $\quad$ Eritrema

- $\quad$ Sedikit eritrema

** Pembengkakan

* $\quad$ Sedikit pembengkakan

$+\quad$ Luka mulai menutup

$\sqrt{ } \quad$ Luka menutup

Proses penyembuhan luka kucing jantan pasca kastrasi dapat dilihat pada gambar di bawah ini:
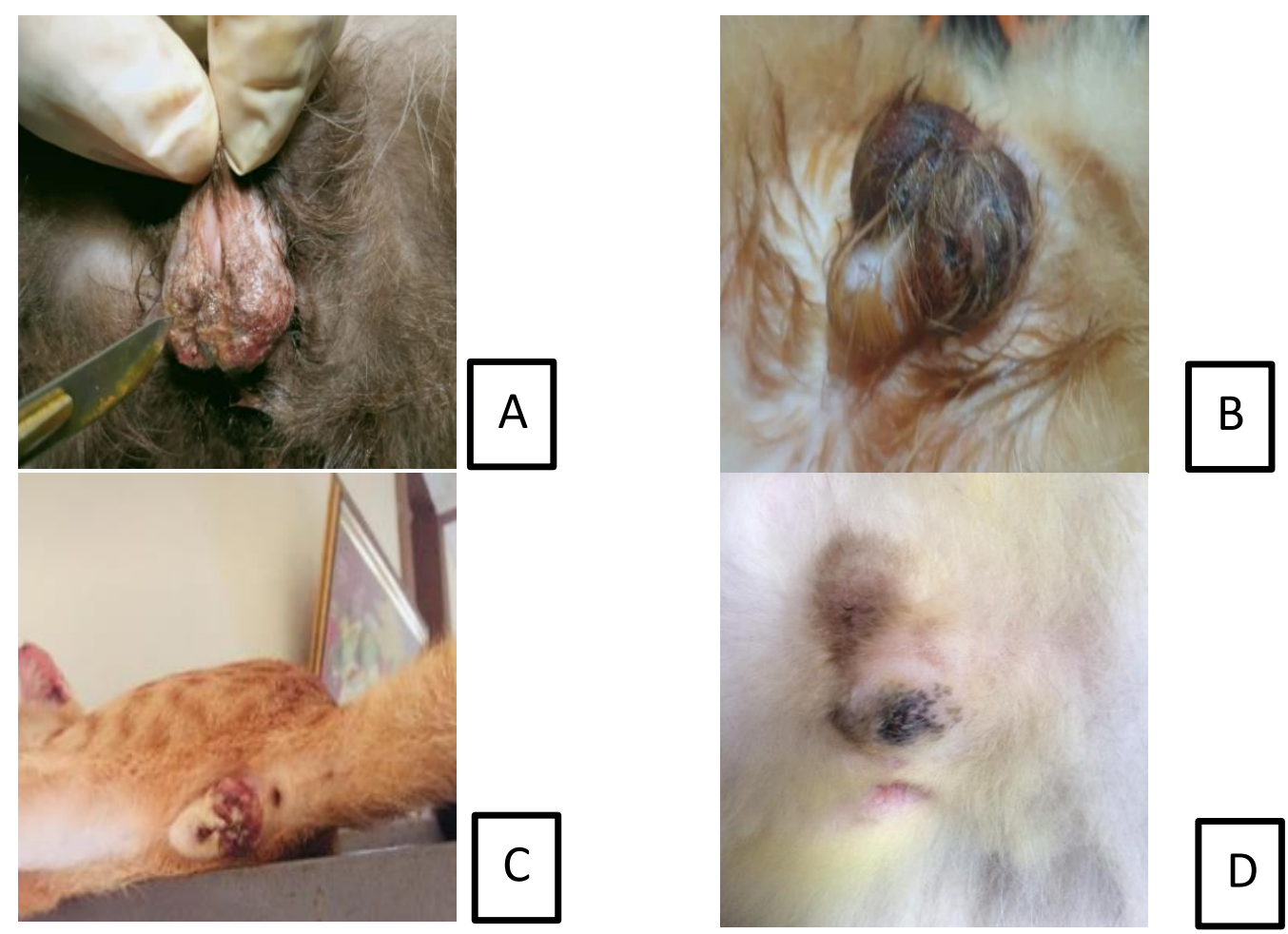

Gambar 2. Proses penyembuhan luka kucing jantan pasca kastrasi 
Keterangan Gambar:

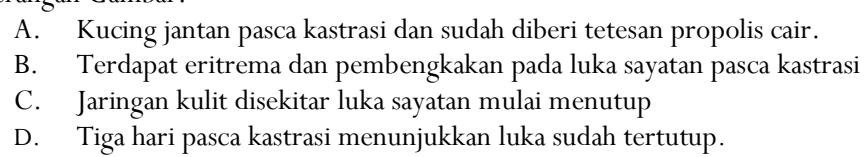

Gambar 2 menjelaskan tahapan penyembuhan luka sayatan operasi kastrasi yaitu dilihat dari (A) sesaat setelah kucing jantan selesai kastrasi, (B) setelah kastrasi terlihat eritrema dan pembengkakan pada lokasi sayatan kulit skrotum, (C) dua hari pasca kastrasi perlukaan mulai menutup dan sudah kering, (D) luka sayatan sudah menutup pada hari ke-3 pasca operasi.

\subsection{Pembahasan}

Hasil penelitian yang dilakukan menunjukkan bahwa awal proses penyembuhan luka dilihat dari eritrema atau kemerahan yang timbul karena pelebaran arteriola yang mensuplai darah ke daerah peradangan sehingga lebih banyak darah mengalir ke mikrosirkulasi lokal, dan kapiler merenggang dengan cepat terisi penuh dengan darah. Keadaan ini disebut juga hyperemia atau kongesti, penyebab warna merah lokal karena peradangan akut. Peregangan dan penuhnya pembuluh darah ditunjukkan oleh adanya kebengkakan (Qomariah, S. et al. 2014). Penyembuhan luka berlangsung dalam 3 fase utama yaitu: fase inflamasi, fase proliferasi, dan fase maturasi atau remodelling (Laut et al, 2019). Proses penyembuhan luka terjadi pada awal inflamasi. Pada proses inflamasi terjadi perusakan, pelarutan, dan penghancuran sel atau agen penyebab kerusakan sel. Pada saat yang sama terjadi proses reparasi, proses pembentukan kembali jaringan rusak atau proses penyembuhan jaringan rusak. Proses ini baru selesai sempurna setelah agen penyebab kerusakan sel dinetralkan (Pebri et al, 2017)

Penggunaan metode kastrasi terbuka pada penelitian ini memiliki kelebihan yang juga berkontribusi pada kecepatan proses penyembuhan. Ikatan pada pembuluh darah dengan menggunakan benang cat gut menghindari terjadinya pendarahan pada saat dilakukan pemotongan jaringan. Pada kastrasi dengan metode terbuka tidak dilakukan penjahitan pada sayatan kulit skrotum dengan tujuan agar luka sayatan bagian dalam skrotum dan luka pada kulit luar cepat mengering. Apabila dilakukan penjahitan kulit luar skrotum, kering atau tidaknya luka dibagian dalam tidak dapat dipastikan karena yang tampak hanya bagian luarnya saja. Kastrasi yang menggunakan metode penjahitan pada kulit skrotum, jahitan kulit wajib dibuka setelah 7 hari pasca operasi. Proses membuka jahitan ini dapat menimbulkan trauma stress tambahan terhadap hewan karena sebelumnya telah mengalami stress pada saat perlakukan operasi kastrasi.

Kucing jantan pasca kastrasi yang diberi perlakuan pengobatan dengan sediaan propolis cair, proses eritrema dan edema (kebengkakan) dilalui dalam kurun waktu yang singkat. Pada satu hari pasca operasi (H.1), dari keseluruhan sampel pada kelompok 1 sebanyak 12 sampel terlihat adanya bentukan eritrema dan edema pada luka sekitar sayatan. Observasi hari kedua (H.2) menunjukkan 10 dari 12 sampel menunjukkaan telah lenyapnya eritrema dan pembengkakan serta mulai menutupnya luka sayatan, hanya sampel (K.2) dan (K.4) yang masih menunjukkan adanya bentukan eritrema dan kebengkakan disekitar luka. Pada hari ketiga (H.3), keseluruhan 12 sampel tidak ditemukan lagi adanya eritrema dan kebengkakan serta luka sayatan sudah mulai menutup. Hari keempat (H.4), kedua belas sampel telah menunjukkan hasil penyembuhan luka yang sempurna.

Dua ekor kucing jantan pada perlakuan kelompok 2 (K.13 dan K.14) menunjukkan hasil penyembuhan luka yang sempurna terjadi pada hari kedua (H.2)., sedangkan 2 ekor yang lainnya (K.15 dan K.16) menunjukkan penyembuhan luka yang sempurna pada hari ketiga (H.3) pasca kastrasi. Dari kedua kelompok perlakuan ini menunjukkan bahwa secara keseluruhan sampel menunjukkan penyembuhan luka sempurna pada hari ketiga (H.3) pasca kastrasi. Pemberian propolis cair yang dilakukan 1 kali sesaat setelah kastrasi ternyata mampu menunjukkan waktu persembuhan luka sayatan kastrasi yang sama dengan pemberian propolis cair yang dilakukan sebanyak 2 kali. Pengamatan lain yang ditemukan pada saat penelitian yaitu pemberian propolis cair mampu memberhentikan pendarahan pada area penampang sayatan baik pada kulit skrotum maupun pada penampang sayatan korda spermatika.

Resistensi antibiotik yang makin lama makin luas karena adanya pemakaian tidak taat aturan dari masyarakat menjadi salah satu faktor yang mendorong pemakaian bahan alam untuk pengobatan. Penggunaan propolis sebagai alternatif pengobatan luka pasca kastrasi selain dapat menghentikan pendarahan, mempercepat proses penyembuhan juga dapat mengurangi penggunaan antibiotika dan dapat mengurangi asupan bahan kimia akibat pemberian obat pada luka yang memungkinkan hewan untuk menjilati permukaan luka. Propolis yang terbuat dari bahan alamiah tidak menimbulkan resistensi antibiotika jika secara tidak sengaja terjilat oleh hewan karena digunakan sebagai obat luar. Propolis mengandung arginine (jenis asam amino) dan asam ferulat (turunan senyawa sinamat) dimana kedua senyawa ini memacu pembentukan kolagen. Dengan meningkatnya jumlah 
kolagen maka proses penyembuhan luka juga akan berlangsung dengan cepat (Serhan, 2006). Propolis mengandung senyawa fenol (flavonoid) dan senyawa lain yang bisa mencegah serangan bakteri, virus dan jamur dari bagian luka bakar yang rentan terhadap infeksi (Mahani et al., 2011).

Menurut Bale et al (2000), proses penyembuhan luka tidak hanya terbatas pada proses regenerasi yang bersifat lokal, tetapi juga dipengaruhi oleh faktor endogen, seperti umur, nutrisi, imunologi, pemakaian obatobatan, dan kondisi metabolik. Keseluruhan kucing jantan yang mendapat perlakuan propolis cair, proses kesembuhan pada umumnya bervariasi antara 3 dan 4 hari pasca kastrasi. Karakter hewan turut menentukan cepat tidaknya kesembuhan luka. Pada kucing dengan karakter tenang, luka akan lebih cepat sembuh karena aktifitas seperti melompat atau gerakan aktif lainnya lebih sedikit sehingga pembentukan jaringan yang baik akan menutup luka lebih sempurna. Sebaliknya untuk kucing dengan karakter sangat aktif seperti lari kencang dan melompat dapat mengakibatkan ikatan jaringan bagian dalam skrotum menjadi putus dan saluran menjadi terbuka. Pada kucing (K.2), luka menutup lebih lama dan masih ditemukan tetesan cairan darah 1 hari pasca kastrasi karena karakter kucingnya yang sangat aktif dan melompat-lompat walaupun sudah dikandangkan dan menggigit-gigit kulit sayatan skrotum. Tindakan yang dapat dilakukan untuk membatasi gerakan pasien pasca operasi diantaranya yaitu hewan dikandangkan dan memakai Elizabeth collar. Observasi hewan pasca tindakan operasi sangat penting untuk dilakukan.

Komplikasi dari kastrasi yang sering terjadi diantaranya adalah trauma, pembengkakan, memar, hematoma skrotalis dan infeksi. Yang paling sering terjadi adalah pembengkakan. Pada penelitian ini, tidak ada satu pun dari kucing yang menunjukkan adanya komplikasi. Ada 2 kucing yang masih menunjukkan sedikit kebengkakan satu hari pasca operasi, hal itu dikarenakan sedang berlangsungnya proses persembuhan. Selain karena pemberian propolis cair, cepat atau tidaknya proses persembuhan tergantung dari besarnya sayatan yang dilakukan. Pada penelitian ini, sayatan pada kulit skrotum sepanjang $1 \mathrm{~cm}$, dan dilakukan agak sedikit ke bagian bawah, tujuannya adalah supaya apabila masih ada cairan pendarahan ataupun cairan lainnya yang berasal dari luka dapat dengan mudah keluar dan tidak tertimbun di bagian dalam skrotum yang nantinya dapat mengakibatkan terjadi infeksi sekunder. Tindakan pembalutan luka sayatan kastrasi juga tidak dilakukan karena selain supaya luka lebih cepat kering, anatomi skrotum kucing yang sulit untuk dilakukan pembalutan.

\section{Kesimpulan}

\subsection{Kesimpulan}

Proses kesembuhan luka sayatan operasi kastrasi pada kulit skrotum kucing jantan yang diobati dengan propolis cair dengan frekuensi pemberian 2 kali yaitu setelah kastrasi dan 2 hari pasca kastrasi membutuhkan waktu 3 hari untuk mencapai kesembuhan sempurna. Proses kesembuhan luka pada kelompok perlakuan yang diberi pengobatan propolis cair 1 kali sesaat setelah kastrasi juga membutuhkan waktu kesembuhan yang sama yaitu selama 3 hari. Faktor-faktor lain yang turut mempercepat persembuhan luka sayatan pada skrotum yaitu penggunaan metode operasi kastrasi dengan metode kastrasi terbuka, tidak dilakukan penjahitan pada kulit skrotum, meminimalisir panjang sayatan kulit, dan tidak dilakukan pembalutan pada luka sayatan. Mengatasi karakter kucing yang agresif dapat dilakukan tindakan seperti pengandangan hewan dan pemakaian Elizabeth collar.

\subsection{Saran}

Perlu penelitian lanjutan khusunya untuk kelompok perlakuan pemberian propolis cair dengan frekuensi pemberian 1 kali yaitu sesaat setelah kastrasi dengan jumlah sampel kucing jantan yang lebih banyak. Selain itu juga dapat dilakukan penelitian lanjutan untuk membandingkan tingkat persembuhan luka dengan menggunakan propolis sediaan lainnya. Hasil penelitian ini sebagai dasar pengembangan terapi untuk pemecahan permasalahan kasus resistensi kuman terhadap antibiotika.

\section{Daftar Referensi}

Abdurrahman, H., Dharmawan, T., \& Pangestu, A. S. (2017). Catstrate : Solusi Menekan Ledakan Populasi Kucing Lokal. Yogyakarta: Universitas Gadjah Mada.

Allen , D., Dyson, D., Pascoe, P., \& O'grady, M. (1986). Evaluation Of A Xylazine-Ketamine Hydrochloride Combination In The Cat. Can J Vet Res, 23-26. 
Arnbjerg, J. (1979). Clinical Use Of Ketamine-Xylazine For Anaesthesia In The Cat. Nord Vet Med, 31(4):14554.

Bale, S., \& Jones, V. (2000). Wound Care Nursing: A Patient-Centred Approach. London: Bailliere Tindall.

Dachlan, E. (2004). Toksoplasmosis Pencegahan Dan Penanggulangannya Pada Ibu Hamil. Proceeding Simposium Nasional Penanganan Dan Penanggulangan Penyakit Sesuai Dengan Kesejahteraan Hewan.

Laut, M., Ndaong, N., Utami, T., Junersi, M., \& Bria Seran, Y. (2019). Efektivitas Pemberian Salep Ekstrak Etanol Daun Anting - Anting (Acalypha Indica Linn.) Terhadap Kesembuhan. Jurnal Kajian Veteriner, Vol. 7 No. $1: 1-11$

Maharani, Karim, R. A., \& Nurjanah, N. (2011). Keajaiban Propolis Trigona. Jakarta: Pustaka Bunda.

Mughniati, S., Kesuma Sari, D., Rendrawan, D., \& Lellah, R. (2018). Pengaruh Ekstrak Biji Kapuk (Ceiba Pentandra Gaertn) Sebagai Obat Kontrasepsi Terhadap Kualitas Spermatozoa Pada Kucing Lokal (Felis Domestica). Jurnal Riset Veteriner Indonesia, 27-34.

Pasupuleti, V., Sammugam, L., Ramesh, N., \& Gan, S. (Published Online 2017 Jul 26). Honey, Propolis, And Royal Jelly: A Comprehensive Review Of Their Biological Actions And Health Benefits. Oxid Med Cell Longev. 2017; 2017: 1259510, Doi: 10.1155/2017/1259510.

Pebri, I., Rinidar, \& Amiruddin. (2017). Pengaruh Pemberian Ekstrak Daun Binahong (Anredera Cordifolia) Terhadap Proses Penyembuhan Luka Insisi (Vulnus Incisivum) Pada Mencit (Mus Musculus). Jimvet, 2(1):01-11.

Qomariah, S., Lisdiana, \& Christijanti, W. (2014). Efektifitas Salep Ekstrak Batang Patah Tulang (Euphorbia Tirucalli) Pada Penyembuhan Luka Sayat Tikus Putih (Rattus Novergicus). Unnes Journal Of Life Science, 79-86.

Rahmiati, D., \& Wira, D. (2019). Induksi Anastesi Menggunakan Ket-A-Xyl® Pada Kucing Domestik. Arshi Vet Lett, 53-54.

Sardjana, I., \& Kusumawati, D. (2011). Bedah Veteriner. Surabaya: Airlangga University Press.

Serhan, C. N. (2006). Resolvins And Protectins: Novel Lipid Mediators In Anti-Inflammation And Resolutions. Scandinavian Journal Of Food And Nutrition.

Susilo, B., Mertaniasih, N., Koendhori, E., \& Mangestuti, A. (2009). Komposisi Kimiawi Dan Aktivitas Antimikroba Propolis. J. Penelit. Med. Eksakta, 23-30. 
[Halaman ini sengaja dikosongkan] 